Accepted

Forest Policy and Economics. - ISSN 1389-9341. - Vol. 71 (2016): 80-86

doi: 10.1016/j.forpol.2015.05.006

\title{
Participatory and Multi-Criteria Analysis for Forest (Ecosystem) Management: A Case Study of Pohorje, Slovenia
}

\author{
Petra Grošelj ${ }^{1}$, Donald G. Hodges ${ }^{2}$, Lidija Zadnik Stirn ${ }^{1}$ \\ ${ }^{1}$ University of Ljubljana, Biotechnical Faculty, Ljubljana, Slovenia, petra.groselj@bf.uni-lj.si; \\ lidija.zadnik@bf.uni-lj.si; \\ ${ }^{2}$ University of Tennessee, Knoxville, TN, USA, dhodges2@utk.edu
}

\begin{abstract}
The primary aims of forest management are to rank and evaluate the effects of forest management scenarios on human communities, landscapes, and the development of forest services, and to achieve a balance between the economic, environmental, social, and cultural uses of forests. Multi-criteria decision methodology offers an effective alternative to address such forest management issues, particularly if they involve multiple stakeholders - including local communities, public representatives, and environmentalists - each of which possess different knowledge, experiences, and prospects. Group methods, based on participatory planning, can be applied to integrate such different interests into an optimal, joint decision. It is for this reason that a new decision model based on a group fuzzy analytic network process was designed. In a case study of the forest area at Pohorje, Slovenia, alternative development scenarios were evaluated by means of the generated model. Six possible management scenarios defined by sustainability indicators were identified. The scenarios were compared and assessed by several stakeholders according to the results of a SWOT analysis. The results reveal that most attention should be devoted to preserved nature, cultural heritage, and local tradition.
\end{abstract}

Keywords: Forest management; Stakeholders; Slovenia; SWOT analysis; Analytic network process; Group decision making; Fuzzy logic 


\section{INTRODUCTION}

Forest management, with its strategic as well as tactical and operational planning, is a very demanding undertaking. In addition to traditional forest management that emphasizes optimizing timber production and the associated financial returns, the natural, cultural, ecological, and social values of forests recently have been incorporated into the broader realm of natural resource management planning. As a consequence, sustainable approaches that protect environmental values and incorporate all forest functions in management decisions are put forward as a multiple criteria decision dilemma (Grošelj and Zadnik Stirn, 2013). Further, stakeholders are now involved in decision making for many forest management situations (Ananda and Herath, 2008). Alternative views, interests, and preferences are included by stakeholders such as forest owners, governmental institutions, non-governmental organizations, and local communities. Thus, the combination of participatory processes and multi criteria decision methods has been demonstrated as an effective tool to rank and evaluate the effects of resource management scenarios on sustainable economic, environmental, social, and cultural uses (Mendoza and Prabhu, 2005; Nordström et al., 2010; Saarikoski et al., 2013)

Strategic planning for natural resource management is based on adjusting to changes in the operational environment, subject to the goals for the use and development of resources. SWOT analysis, a structured method to evaluate the strengths, weaknesses, opportunities, and threats of the problem, is a common tool for evaluating environmental issues and forest ecosystems (Marino et al., 2014; Rauch, 2007). It offers a systematic approach, supports decision making, and allows stakeholder inclusion. It can serve as a solid basis for environmental analysis. Because of the complexity of forest management problems, however, this approach is not adequate in many cases. SWOT analysis provides only a qualitative analysis of the internal and 
external factors and also fails to evaluate possible decisions according to these factors (Kajanus et al., 2004). As a result, many researchers have attempted to improve and upgrade SWOT analysis, including developing a hybrid method, A'WOT, that integrates an analytic hierarchy process (AHP) and SWOT analysis (Gallego-Ayala and Juízo, 2011; Kajanus et al., 2012; Kangas et al., 2003; Kurttila et al., 2000; Leskinen et al., 2006; Margles et al., 2010; Masozera et al., 2006; Pesonen et al., 2001; Shinno et al., 2006), and combining SWOT and analytic network project (ANP) (Catron et al., 2013; Kazemi et al., 2009; Wei et al., 2011). In other research fields, SWOT analysis has been integrated with many other multi criteria decision making methods (MCDM), including fuzzy AHP (Kahraman et al., 2008; Lee et al., 2009c; Zadnik Stirn, 2006; Zavadskas et al., 2011), fuzzy ANP (Amin et al., 2011; Chen et al., 2010; Lee et al., 2009b; Sevkli et al., 2012; Shakoor Shahabi et al., 2014; Yüksel and Dag`deviren, 2007), TOPSIS and fuzzy TOPSIS (Azimi et al., 2011; Bas, 2013), and fuzzy quality function deployment (Manteghi and Zohrabi, 2011; Pur and Tabriz, 2012).

The aim of this paper is to offer a new approach for handling complex, vague forest management problems with many parameters and variables that also allows for evaluating potential scenarios, while accounting for the opinions of multiple stakeholders. We propose a two-step approach based on SWOT analysis and group AHP. A fuzzy concept is included in the approach as well to enable a convenient environment for including stakeholder opinions, and a new group aggregation method in AHP is proposed to incorporate stakeholder opinions into one group opinion. The model then is applied to a case study of a forest ecosystem management problem at Pohorje, Slovenia. Section 2 presents the new approach, followed by a revision of the AHP, fuzzy AHP, and ANP methods, and a presentation of the new group fuzzy AHP. Section 3 describes the case study for Pohorje; section 4 discusses the implications of the results and section 5 presents the main conclusions. 


\section{METHODS}

\section{Two-step evaluation framework}

MCDM is widely used for solving complex problems with various supplementary, often conflicting criteria. It offers a powerful tool by enabling a formal structuring of the problem and providing instruments for analyzing and interpreting the results (Mendoza and Prabhu, 2005). To meet the main objective of this paper, that is, to rank and/or evaluate management scenarios with respect to the criteria from a SWOT analysis, we developed a two-step evaluation procedure consisting of:

Step 1: SWOT analysis and evaluation of SWOT groups through applying fuzzy group AHP. Step 2: Evaluation of scenarios regarding the SWOT groups using AHP or its upgraded procedure, assigned as an ANP approach.

\section{Step 1}

The objective of the process must be clearly defined by a leader or a group of decision makers at the beginning of the decision making process. Next, potential stakeholders are identified and invited to take part in the decision process. In order to perform the SWOT analysis, significant factors in the external and internal environments must be identified. The SWOT analysis is completed as a part of a participatory process in which stakeholders participate in meetings, workshops, or through a web platform. The stakeholders identify and rank the SWOT factors, after which the highest ranked factor is chosen to represent the SWOT group (Pesonen et al., 2001). A group of carefully selected stakeholders who are experts in their fields is invited to the next phase where the SWOT groups are ranked using AHP. In this phase each stakeholder compares the SWOT groups regarding the objective in a pairwise fashion. A new fuzzy aggregation approach is proposed to incorporate individual judgments into the group judgment. 
Step 2

In the second step, all possible scenarios are identified with the support of stakeholders. Next, a hierarchy or network for the main goal, SWOT groups, and scenarios are created and all pairwise comparisons used in the AHP procedure are obtained by the stakeholders. The final result is a vector of weights, and on this basis, the discussed scenarios are ranked.

The AHP and its varieties are presented in the following subsections.

\section{Analytic hierarchy process}

AHP (Saaty, 1980) is a well-known subjective weighting approach for assessing the priorities of the criteria. The AHP procedure is composed of three stages: 1) construction of the hierarchical structure of the problem; 2) pairwise comparisons of factors (criteria, alternatives) on the same level of hierarchy and derivation of weights for each level; and 3) synthesis of weights to gain global weights. This tool uses Saaty's 9-point scale to express the relative preference of one factor over another in stage two. The eigenvector method (Saaty, 1980) can be applied to derive a vector of weights from the comparison matrix. The consistency of comparisons is measured by the consistency ratio:

$$
C R=\frac{C I}{R I}, C I=\frac{\lambda_{\max }-n}{n-1},
$$

where $\lambda_{\max }$ denotes the maximal eigenvalue of $n \times n$ comparison matrix and $R I$ denotes a random index. According to Saaty (2005), $C R<0.1$ is considered acceptable.

\section{Fuzzy analytic hierarchy process}

Fuzzy set theory (Zadeh, 1965) has been used in decision making processes to express uncertain and vague information often gained from decision makers' judgments. In order to enable 
decision makers to use linguistic expressions rather than numbers and efficiently convey human perceptions, a fuzzy AHP approach was developed (Heo et al., 2012). Among the many fuzzy AHP methods (Buckley, 1985; Deng, 1999; Stam et al., 1996; Van Laarhoven and Pedrycz, 1983) the extent analysis method (Chang, 1996) is the most popular. In this study, a modified extent analysis method (Heo et al., 2010; Heo et al., 2012; Wang and Elhag, 2006; Wang et al., 2008; Zhu et al., 1999) that presents an improved version of Chang's method was applied. It utilizes triangular fuzzy numbers (TFN) $\tilde{a}_{i j}=\left(l_{i j}, m_{i j}, u_{i j}\right)$ for pairwise comparison scale. Let

$$
\tilde{A}=\left(\tilde{a}_{i j}\right)_{n \times n}=\left[\begin{array}{cccc}
(1,1,1) & \left(l_{12}, m_{12}, u_{12}\right) & \cdots & \left(l_{1 n}, m_{1 n}, u_{1 n}\right) \\
\left(l_{21}, m_{21}, u_{21}\right) & (1,1,1) & \cdots & \left(l_{2 n}, m_{2 n}, u_{2 n}\right) \\
\vdots & \vdots & & \vdots \\
\left(l_{n 1}, m_{n 1}, u_{n 1}\right) & \left(l_{n 2}, m_{n 2}, u_{n 2}\right) & \cdots & (1,1,1)
\end{array}\right]
$$

be a triangular fuzzy comparison matrix where $\tilde{a}_{i j}=\tilde{a}_{j i}^{-1}=\left(1 / u_{i j}, 1 / m_{i j}, 1 / l_{i j}\right)$ for $i, j=1, \ldots, n$ To calculate the vector of weights from the triangular fuzzy comparison matrix, first the normalized synthetic extents with respect to the $i$-th object are defined (Wang et al., 2008) according to eq.(3).

$$
S_{i}=\left(\frac{\sum_{j=1}^{n} l_{i j}}{\sum_{j=1}^{n} l_{i j}+\sum_{k=1, k \neq i}^{n} \sum_{j=1}^{n} u_{k j}}, \frac{\sum_{j=1}^{n} m_{i j}}{\sum_{k=1}^{n} \sum_{j=1}^{n} m_{k j}}, \frac{\sum_{j=1}^{n} u_{i j}}{\sum_{j=1}^{n} u_{i j}+\sum_{k=1, k \neq i}^{n} \sum_{j=1}^{n} l_{k j}}\right), i=1, \ldots, n
$$

where fuzzy arithmetic operations were considered. Second, the degree of possibility of $S_{i}=\left(l_{i}, m_{i}, u_{i}\right) \geq S_{j}=\left(l_{j}, m_{j}, u_{j}\right)$ is defined by eq.(4) (Chang, 1996).

$$
V\left(S_{i} \geq S_{j}\right)= \begin{cases}1, & \text { if } \mathrm{m}_{\mathrm{i}} \geq \mathrm{m}_{\mathrm{j}} \\ 0, & \text { if } \mathrm{l}_{\mathrm{j}} \geq \mathrm{u}_{\mathrm{i}} \\ \frac{l_{j}-u_{i}}{\left(m_{i}-u_{i}\right)-\left(m_{j}-l_{j}\right)}, & \text { otherwise }\end{cases}
$$

Next, for calculating the degree of possibility of a fuzzy number $S$ to be greater than $k$ fuzzy numbers $S_{i}, i=1, \ldots, k$ eq.(5) is used. 


$$
V\left(S \geq S_{1}, S_{2}, \ldots, S_{k}\right)=\min _{i=1, \ldots, k} V\left(S \geq S_{i}\right)
$$

Denoting

$$
d^{\prime}\left(A_{i}\right)=\min _{k=1, \ldots, n ; k \neq i} V\left(S_{i} \geq S_{k}\right)
$$

the non-fuzzy vector of weights can be derived as

$$
W^{\prime}=\left(d^{\prime}\left(A_{1}\right), d^{\prime}\left(A_{2}\right), \ldots, d^{\prime}\left(A_{n}\right)\right)
$$

and then normalized to a vector of weights $W$.

\section{Group fuzzy analytic hierarchy process}

When a group of stakeholders is involved in a decision making process it is necessary to summarize individual preferences into one preference representing the group's opinion. The geometric mean method, where the geometric mean of individual pairwise comparisons represents the group pairwise comparison is widely used in the literature (Ananda and Herath, 2008; Cortés-Aldana et al., 2009; De Luca, 2014; Lee et al., 2009a; Oblak and Glavonjić, 2015; Srdjevic et al., 2013; Sun and Li, 2009). It is convenient as a mean since it fulfills some necessary axiomatic conditions as reciprocity. But this method could be unsatisfactory for group decision making, since one number can hardly express a group opinion that is not exactly defined because of the dispersion of individual judgments (Jaskowski et al., 2010; Regan et al., 2006). We believe a fuzzy number approach could be more suitable for this task. Chang et al. (2009) proposed to aggregate individual judgments of $m$ stakeholders in the form of fuzzy numbers $\tilde{a}_{i j}=\left(l_{i j}, m_{i j}, u_{i j}\right)$ with

$$
l_{i j}=\min _{k=1, \ldots, m} a_{i j}{ }^{(k)}, m_{i j}=\sqrt[m]{\prod_{k=1}^{m} a_{i j}{ }^{(k)}}, u_{i j}=\max _{k=1, \ldots, m} a_{i j}{ }^{(k)}
$$

This method assumes a uniform distribution of judgments and could be inappropriate for data that have extreme outliers. Hence, we propose a new aggregation approach based on a fuzzy 
AHP scale. There are more than 25 definitions of membership functions for the fuzzy scale in the literature (Ishizaka and Nguyen, 2013). The selected triangular fuzzy scale is presented in Table 1. It utilizes numbers 1 to 9 as in the classical AHP and has been used in many applications (Aghdaie et al., 2012; Lee and Lin, 2008; Lei et al., 2010; Lima Junior et al., 2014; Punniyamoorthy et al., 2011). If fuzzy number $\tilde{1}$ is assigned to pairwise comparison it presents TFN $(1,1,3)$. TFN $(1,1,1)$ is used only when element is compared with itself.

The group fuzzy pairwise comparison is presented by TFN $\tilde{a}_{i j}{ }^{G}=\left(l_{i j}{ }^{G}, m_{i j}{ }^{G}, u_{i j}{ }^{G}\right)$. The base of our new aggregation approach is the geometric mean of individual judgments that represents the middle of the fuzzy group number $m_{i j}{ }^{G}$, where the pertinence degree is maximal. According to the fuzzy scale (Table 1) and employing fuzzy arithmetic operations, $l_{i j}{ }^{G}$ and $u_{i j}{ }^{G}$ are derived. As an example:

$$
\text { If } m_{i j}{ }^{G}=3.35 \text {, then } \tilde{a}_{i j}{ }^{G}=0.825 \cdot(1,3,5)+0.175 \cdot(3,5,7)=(1.35,3.35,5.35) \text {. }
$$

Group fuzzy pairwise comparisons are gathered in a group fuzzy comparison matrix $\tilde{A}^{G}$. Modified analysis extend method is applied to derive group weights.

\section{Analytic network process}

If there are more complex interrelationships between elements of decision making, a hierarchical structure could be too rigorous. Therefore, it could be replaced by network structure (Saaty, 2005). In the ANP approach, vectors of weights are derived as in AHP. Vectors of weights from all levels are combined in an unweighted super matrix, in which blocks are multiplied by the elements from the comparison matrix of clusters resulting in a weighted super matrix. The final weights are obtained from the limit super matrix. 


\section{CASE STUDY FOR POHORJE, SLOVENIA}

Slovenia is one of the most forested countries in Europe, with forests covering $57.7 \%$ of its territory (Debevc, 2005). The Pohorje region lies in northeastern Slovenia (Figure 1) and covers $840 \mathrm{~km}^{2}$. The majority of the area is listed under Natura 2000 (UL, 2004). Seventy percent of Pohorje is covered with forests that, with tourism and agriculture, represent the most important economic opportunities for the region. There are several popular recreational centers at Pohorje, with alpine and cross-country skiing offered in winter, and trekking and cycling in summer.

Our study was part of the NATREG project (NATREG, 2011b), which is designed to identify and promote the potential of natural assets and protected areas as drivers of sustainable regional development and to increase the perception of preserved nature as a valuable asset. The project was managed by the Institute of the Republic of Slovenia for Nature Conservation. The primary aim of our study was to rank six possible scenarios for Pohorje regarding their contribution to the realization of the "Pohorje 2030" vision (Hojnik, 2011).

\section{Step 1}

In the first step stakeholders were selected (Smajić Hodžić, 2010) from ministries; municipalities; public institutions; educational institutions; and private entities from the tourism, forestry, agriculture, education, and nature protection sectors. Next, selected stakeholders were invited to the workshops. Stakeholders at the workshops were assigned to small groups to form SWOT factors, followed by reporting and adjusting the groups' results. The final SWOT analysis was a result of sector workshops (for forestry, agriculture, and tourism (Lešnik Štuhec and Gulič, 2010) and a joint workshop (Krajčič, 2011; Uratarič and Marega, 2010), which was attended by 38 stakeholders from different sectors. The stakeholders also 
ranked the SWOT factors. The factor with the highest number of points was selected as representative of the SWOT group for further treatment (Table 3). SWOT groups were compared by a group of 12 stakeholders well acquainted with Pohorje's problems, and with expertise in forestry, agriculture, tourism, and nature protection. All surveys were conducted in individual meetings. Therefore, all questions and particularities of the AHP method could be immediately explained to the stakeholder, reducing the demands on the participants. Their judgments were aggregated into fuzzy group judgments for SWOT groups. The group fuzzy matrix $\tilde{A}_{\text {SWOT }}$ presents the result of aggregation of all 12 stakeholders.

$$
\tilde{A}_{\text {SWOT }}=\left[\begin{array}{cccc}
(1,1,1) & (1.00,1.35,3.35) & (0.29,0.70,1.00) & (1.00,1.13,3.13) \\
(0.30,0.74,1.00) & (1,1,1) & (0.29,0.67,1.00) & (1.00,1.18,3.18) \\
(1.00,1.42,3.42) & (1.00,1.49,3.49) & (1,1,1) & (1.00,1.37,3.37) \\
(0.32,0.89,1.00) & (0.32,0.85,1.00) & (0.30,0.73,1.00) & (1,1,1)
\end{array}\right] \text { (10) }
$$

Modified extent analysis method was applied to determine fuzzy synthetic extents (3).

$$
\begin{aligned}
& S_{1}=(0.133,0.253,0.499) \\
& S_{2}=(0.098,0.218,0.401) \\
& S_{3}=(0.177,0.319,0.591) \\
& S_{4}=(0.069,0.210,0.288)
\end{aligned}
$$

The degrees of possibility between fuzzy synthetic extents (4) are gathered in Table 2.

Normalized final weights of SWOT factors (7) are presented in Table 3.

\section{Step 2}

One of the NATREG project results was the "Pohorje 2030” vision (Hojnik, 2011) and six scenarios supporting the realization of the "Pohorje 2030" vision. These scenarios were prepared by a group of experts and extended by stakeholders within a workshop. The six scenarios were identified as: Cooperation of stakeholders and improved quality of living, Biodiversity preservation and protection of natural values, Sustainable tourism development, 
Adopted exploitation of natural resources, Sustainable and environmentally friendly traffic regulation, and Employing the potential of cultural heritage (NATREG, 2011a)

The "Cooperation of stakeholders and improved quality of living” refers to the integration of stakeholders in the area in decision making and accessibility of information for the local population. At the same time, the objective relates to the provision of quality living conditions (e.g., basic and superior life infrastructure, the right to live in a healthy environment), which form the basis for the maintenance or expansion of the economically active populations in the area and raising the quality of services for visitors. The indicators that measure this scenario are: interregional association and three regional associations of local populations, zoning, establishing a single operator to the area (e.g., Park Pohorje), number of inhabitants, proportion of the working age population, and value of investments in residential facilities.

The aim of "Biodiversity preservation and protection of natural values" is biodiversity conservation (habitat types and animal and plant species), natural value protection, and protection of the landscape and its core attributes (open areas - pastures, individual trees on flat land, the relationship between forest and non-forest areas, forest edge, and associated agricultural land and forests). The indicators that measure this scenario include diversity levels of species and habitat types, degree of circularity of the area, preservation of exceptional landscape patterns, and condition of natural values.

"Sustainable tourism development" refers to the sustainable development of the area; establishing sustainable tourism infrastructure; creating networks of similar types of providers to promote quality growth and development; and communication to meet the needs of visitors, tourism businesses, and local residents. Indicators for assessing this scenario are: innovation 
and creativity to experience nature and cultural heritage, recognition of sustainable destinations at Pohorje, traditional and environmental engineering and implementation of activities in the area, quality and coordination of local supply, and degree of organization for the sustainable destination of Pohorje.

The "Adopted exploitation of natural resources" (mainly wood, grass, water, stone, wildlife, non-forest products) refers to the use of all natural resources that can be exploited under existing policies. Exploitation of natural resources should provide a lasting contribution to economic and social development, especially in rural areas, in a way that recognizes the natural ability of ecosystem restoration. The indicators that measure the realization of this scenario include exploited natural resources, trends in natural resource exploitation, fields of resource usage, number of farms and businesses involved in resource exploitation, and the amount of resources dedicated to promote and fund exploitation of natural resources.

"Sustainable and environmental friendly traffic regulation" refers to the regulation of traffic and transport links in the area. Pohorje is crisscrossed by numerous roads. Ideally, transportation networks for residents should be separate from those frequented by visitors, with an emphasis on reducing the number of visitors who travel in tourist centers in personal vehicles. In the immediate vicinity the focus will be on environmentally friendly forms of transport (gas and electric vehicles, bicycles). Assessment metrics include transportation regimes, road safety, quality of public transportation, and alternative forms of transportation and intermodality.

"Employing the potential of cultural heritage" refers to the preservation of local architecture and encouraging investors to consider these characteristics. Development potential of cultural heritage and local traditions, as well as the integration of local and regional events arising from 
cultural heritage, should be considered. This scenario can be assessed by the criteria and guidelines developed to evaluate the importance of local architecture and the efficiency of the system of stimulations (renovation and new constructions), sustainable use of heritage and local traditions in tourism, local concept of sustainable use, number of events to popularize cultural heritage at the local and regional levels, coordination of cultural events, and number of cultural - educational programs.

The scenarios are not necessarily exclusive alternatives but rather supplementary goals which all could be achieved in realizing the "Pohorje 2030" vision. Therefore the object of the second step was to rank the scenarios, not select the most important one. SWOT groups would affect the scenarios and the realization of the scenarios would invigorate strengths, reduce weaknesses, take advantage of opportunities, and avoid threats. These connections indicate that network structure of the evaluation framework should be in the form depicted in Figure 2.

We compared scenarios with regard to SWOT groups (e.g., which scenarios will make better use of the strengths), and compared SWOT groups with regard to scenarios. This was accomplished using the classical 1-9 AHP scale and eigenvector method for deriving weights. The weights were combined with the weights from Step 1 in an unweighted super matrix (Table 4). It is already stochastic; therefore, weighting the clusters is not required.

Limit super matrix was derived by Super Decisions software (Decisions, 2000). Table 5 presents the final weights and ranking of scenarios.

The results reveal that 'Biodiversity preservation and protection of natural values' was the most important scenario with 25\%, followed by 'Employing the potential of cultural heritage' at 
24.4\%. Implementing projects that address the preservation of nature and cultural heritage will bring these scenarios into effect and accomplish the "Pohorje 2030” vision. Such projects could improve the condition of forest habitat types and forest species (adopt forest management, establish networks of eco-cells, and monitoring species), maintain pastures and wetlands and enhance their sustainable management, raise the quality of traditional activities and infrastructure, and enhance the identity of rural Pohorje. 'Sustainable and environmental friendly traffic regulation', 'Adopted exploitation of natural resources', and 'Sustainable tourism development' were scenarios that ranked third to fifth, with similar weights. The scenario with the smallest weight of $8.5 \%$ was 'Cooperation of stakeholders and improved quality of living' which indicates that stakeholders have not recognized cooperation as an important factor for attaining the desired development of Pohorje.

\section{DISCUSSION}

Incorporating multiple stakeholder objectives and opinions in sustainable forest management decision making has perplexed managers and decision makers for decades. While traditional SWOT analysis has been a useful framework, the proposed two-step process provides the advantage of evaluating several potential scenarios simultaneously while accounting for the opinions of multiple stakeholders. Such an approach will become even more critical as we face increasingly complex decisions involving land use conflicts and multiple, and often conflicting, ecosystem service management alternatives. An additional advantage of the proposed methodology is that it would provide stakeholders with information regarding the trade-offs inherent in their preferences and allow for changes as the decision making process progresses. 
The final results of the case study reveal that all scenarios could be partially adopted in order to fulfill the "Pohorje 2030” vision. The implementation of the scenarios is further supported by the operational goals defined by the program for each scenario (NATREG, 2011a) and the NATREG Action Plan (Stare et al., 2011). The Action Plan consists of numerous actions in the form of project ideas that contribute to achieving the vision, operative goals, and scenarios for sustainable development in Pohorje. The Action Plan was presented to the stakeholders at the concluding workshop (Stare and Gulič, 2011) at which the stakeholders evaluated the results as useful and participation as positive (Danev, 2011). They called for strengthening cooperation between different organizations and individuals that could lead to the establishment of Park Pohorje.

The two-step approach presented here upgrades the traditional SWOT analysis with an evaluation of scenarios linked in the ANP model. Many applications of jointly using SWOT and multi-criteria decision method demonstrate the desirability of this combination as a promising approach to participatory planning processes (Kajanus et al., 2012). It enables decision makers to consider qualitative and quantitative factors. Many decision makers are acquainted with SWOT analysis and employ it in the participatory decision making processes which could simplify introducing the new approach.

Step 1 of the proposed evaluation framework employs only the highest ranked factor to represent the SWOT group. The results indicate that some information regarding the SWOT factors is lost but the framework significantly reduces the number of required pairwise scenario comparisons. Preserving all SWOT factors would require pairwise comparisons of scenarios with respect to all SWOT factors, instead of only with respect to SWOT groups. 
The integrated network structure enables interdependencies to be considered, which could be significant in complex environments such as sustainable forest management and provide more accurate results. The introduction of fuzzy numbers in the aggregation process of individual judgments considers uncertainty in stakeholders' opinions. We can conclude that the proposed two-step approach provides an operational framework for sustainable forest management as well as many other strategic decision making situations.

\section{CONCLUSIONS}

Complex real problems in forest management often require multidisciplinary approaches and therefore inclusion of various stakeholders in the decision making process. A new evaluation framework combining fuzzy AHP/ANP and SWOT analysis proved to be an effective tool for handling such problems. The new aggregation group approach which is based on fuzzy AHP offers a new possibility to deal with opinions of several stakeholders.

The results of the case study reveal that 'Biodiversity preservation and protection of natural values' and 'Employing the potential of cultural heritage' were the two most popular scenarios. These results indicate that sustainable development of Pohorje is the most promising way to implement the "Pohorje 2030" vision. It includes protection of nature, biodiversity, and cultural heritage; and sustainable management of traffic, tourism, and natural resource use. With regard to the SWOT analysis, opportunities were most important for Pohorje development; with strengths being the second most important. Sustainable development has the advantage of capturing all strengths identified in the SWOT analysis. It also annuls all identified weaknesses and avoids most threats. 
The proposed approach is appropriate for addressing similar problems in forestry and environmental management. Further research should investigate the inclusion of combinations of other fuzzy approaches such as fuzzy TOPSIS, fuzzy COPRAS, and others in the evaluation framework in addition to AHP/ANP in order to compare their results and gain more robust results on every level of decision making.

\section{Acknowledgement}

We are grateful to Dr. Darij Krajčič and Gregor Danev from The Institute of the Republic of Slovenia for Nature Conservation for all data from the NATREG project.

Petra Grošelj acknowledges financial support from Slovenian Research Agency within the framework of Program P4-0059.

\section{REFERENCES}

Aghdaie, M.H., Zolfani, S.H., Zavadskas, E.K., 2012. Market segment evaluation and selection based on application of fuzzy AHP and COPRAS-G methods. Journal of Business Economics and Management 14, 213-233.

Amin, S.H., Razmi, J., Zhang, G., 2011. Supplier selection and order allocation based on fuzzy SWOT analysis and fuzzy linear programming. Expert Systems with Applications 38, 334-342.

Ananda, J., Herath, G., 2008. Multi-attribute preference modelling and regional land-use planning. Ecological Economics 65, 325-335. 
Azimi, R., Yazdani-Chamzini, A., Fouladgar, M.M., Zavadskas, E.K., Basiri, M.H., 2011. Ranking the strategies of mining sector through anp and topsis in a swot framework. Journal of Business Economics and Management 12, 670-689.

Bas, E., 2013. The integrated framework for analysis of electricity supply chain using an integrated SWOT-fuzzy TOPSIS methodology combined with AHP: The case of Turkey. International Journal of Electrical Power \& Energy Systems 44, 897-907.

Buckley, J.J., 1985. Fuzzy hierarchical analysis. Fuzzy Sets and Systems 17, 233-247.

Catron, J., Stainback, G.A., Dwivedi, P., Lhotka, J.M., 2013. Bioenergy development in Kentucky: A SWOT-ANP analysis. Forest Policy and Economics 28, 38-43.

Chang, C.-W., Wu, C.-R., Lin, H.-L., 2009. Applying fuzzy hierarchy multiple attributes to construct an expert decision making process. Expert Systems with Applications 36, 7363-7368.

Chang, D.-Y., 1996. Applications of the extent analysis method on fuzzy AHP. European Journal of Operational Research 95, 649-655.

Chen, H.H., Kang, H.-Y., Lee, A.H.I., 2010. Strategic selection of suitable projects for hybrid solar-wind power generation systems. Renewable and Sustainable Energy Reviews 14, 413421.

Cortés-Aldana, F.A., García-Melón, M., Fernández-de-Lucio, I., Aragonés-Beltrán, P., PovedaBautista, R., 2009. University objectives and socioeconomic results: A multicriteria measuring of alignment. European Journal of Operational Research 199, 811-822.

Danev, G., 2011. Rezultati delavnice o zadovoljstvu s projektom [Results of the workshop on satisfaction with the project], p. 4, 
http://www.natreg.eu/pohorje/uploads/datoteke/2011_07_12_MB_rezultati\%20delavnice.pdf, Accessed 27. 3. 2015.

De Luca, S., 2014. Public engagement in strategic transportation planning: An analytic hierarchy process based approach. Transport Policy 33, 110-124.

Debevc, B., 2005. Slovenia Forest Service, Slovenia Forest Service, Ljubljana, p. 11.

Decisions, S. (2000) Super Decisions. Creative Decisions Foundation. http://www.superdecisions.com. Accessed 27. 3. 2015.

Deng, H., 1999. Multicriteria analysis with fuzzy pairwise comparison. International Journal of Approximate Reasoning 21, 215-231.

Gallego-Ayala, J., Juízo, D., 2011. Strategic implementation of integrated water resources management in Mozambique: An A’WOT analysis. Physics and Chemistry of the Earth, Parts A/B/C 36, 1103-1111.

Grošelj, P., Zadnik Stirn, L., 2013. Between compromise and consensus in group decisions in forest management. Šumarski list 137, 403-410.

Heo, E., Kim, J., Boo, K.-J., 2010. Analysis of the assessment factors for renewable energy dissemination program evaluation using fuzzy AHP. Renewable and Sustainable Energy Reviews 14, 2214-2220.

Heo, E., Kim, J., Cho, S., 2012. Selecting hydrogen production methods using fuzzy analytic hierarchy process with opportunities, costs, and risks. International Journal of Hydrogen Energy 37, 17655-17662. 
Hojnik, M., 2011. Vizija območja - Pohorje 2030 [The vision of the area - Pohorje 2030]; project NATREG. The Institute of the Republic of Slovenia for Nature Conservation Ljubljana, p. 1.

Ishizaka, A., Nguyen, N.H., 2013. Calibrated fuzzy AHP for current bank account selection. Expert Systems with Applications 40, 3775-3783.

Jaskowski, P., Biruk, S., Bucon, R., 2010. Assessing contractor selection criteria weights with fuzzy AHP method application in group decision environment. Automation in Construction 19, $120-126$.

Kahraman, C., Demirel, N., Demirel, T., Ateş, N., 2008. A SWOT-AHP Application Using Fuzzy Concept: E-Government in Turkey, in: Kahraman, C. (Ed.), Fuzzy Multi-Criteria Decision Making. Springer US, pp. 85-117.

Kajanus, M., Kangas, J., Kurttila, M., 2004. The use of value focused thinking and the A`WOT hybrid method in tourism management. Tourism Management 25, 499-506.

Kajanus, M., Leskinen, P., Kurttila, M., Kangas, J., 2012. Making use of MCDS methods in SWOT analysis-Lessons learnt in strategic natural resources management. Forest Policy and Economics 20, 1-9.

Kangas, J., Kurttila, M., Kajanus, M., Kangas, A., 2003. Evaluating the management strategies of a forestland estate- the S-O-S approach. Journal of Environmental Management 69, 349358.

Kazemi, M., Mohammadi, I.M., Samari, D., 2009. Sustainable Management of Natural Resources and Extension strategies: an application of ANP, in: Tjader, Y., Tamewitz, J. (Eds.), ISAHP2009 Proceedings. University of Pittsburgh, Pittsburgh, p. 19. 
Krajčič, D., 2011. Process of recognizing the local potentials as a basis for sustainable development. Zbornik gozdarstva in lesarstva 96, 35-46.

Kurttila, M., Pesonen, M., Kangas, J., Kajanus, M., 2000. Utilizing the analytic hierarchy process (AHP) in SWOT analysis -- a hybrid method and its application to a forest-certification case. Forest Policy and Economics 1, 41-52.

Lee, A.H.I., Chang, H.-J., Lin, C.-Y., 2009a. An evaluation model of buyer-supplier relationships in high-tech industry - The case of an electronic components manufacturer in Taiwan. Computers \& Industrial Engineering 57, 1417-1430.

Lee, A.H.I., Chen, H.H., Kang, H.-Y., 2009b. Multi-criteria decision making on strategic selection of wind farms. Renewable Energy 34, 120-126.

Lee, K.-L., Huang, W.-C., Teng, J.-Y., 2009c. Locating the competitive relation of global logistics hub using quantitative SWOT analytical method. Qual Quant 43, 87-107.

Lee, K.-L., Lin, S.-C., 2008. A fuzzy quantified SWOT procedure for environmental evaluation of an international distribution center. Information Sciences 178, 531-549.

Lei, F., Li, S., Ying, Y., Bengong, Y., 2010. The selection of project management software by FAHP and FMCDM in automobile R\&D process, 2nd International Conference on Networking and Digital Society (ICNDS), pp. 66-69.

Leskinen, L.A., Leskinen, P., Kurttila, M., Kangas, J., Kajanus, M., 2006. Adapting modern strategic decision support tools in the participatory strategy process-a case study of a forest research station. Forest Policy and Economics 8, 267-278.

Lešnik Štuhec, T., Gulič, J., 2010. Poročilo o opravljenih SWOT analizah na področjih gozdarstva, kmetijstva in turizma na Pohorju [Report of sectors (forestry, agriculture, tourism) 
SWOT analysis of Pohorje], project: NATREG, p. 37, http://www.zrsvn.si/dokumenti/64/2/2010/141010_SWOT_TLS_JGk_2125.pdf, Accessed 27. 3. 2015.

Lima Junior, F.R., Osiro, L., Carpinetti, L.C.R., 2014. A comparison between Fuzzy AHP and Fuzzy TOPSIS methods to supplier selection. Applied Soft Computing 21, 194-209.

Manteghi, N., Zohrabi, A., 2011. A proposed comprehensive framework for formulating strategy: a Hybrid of balanced scorecard, SWOT analysis, porter`s generic strategies and Fuzzy quality function deployment. Procedia - Social and Behavioral Sciences 15, 2068-2073.

Margles, S.W., Masozera, M., Rugyerinyange, L., Kaplin, B.A., 2010. Participatory Planning: Using SWOT-AHP Analysis in Buffer Zone Management Planning. Journal of Sustainable Forestry 29, 613-637.

Marino, E., Hernando, C., Planelles, R., Madrigal, J., Guijarro, M., Sebastián, A., 2014. Forest fuel management for wildfire prevention in Spain: a quantitative SWOT analysis. International Journal of Wildland Fire 23, 373-384.

Masozera, M.K., Alavalapati, J.R.R., Jacobson, S.K., Shrestha, R.K., 2006. Assessing the suitability of community-based management for the Nyungwe Forest Reserve, Rwanda. Forest Policy and Economics 8, 206-216.

Mendoza, G.A., Prabhu, R., 2005. Combining participatory modeling and multi-criteria analysis for community-based forest management. Forest Ecology and Management 207, 145156. 
NATREG, 2011a. Cilji predloga načrta upravljanja za pilotno območje Pohorje [Goals of the draft of the management plan of pilot area Pohorje], p. 21, http://www.natreg.eu/pohorje/uploads/datoteke/3_\%20CILJI.pdf, Accessed 9. maj 2012.

NATREG (2011b) NATREG: Managing Natural Assets and Protected Areas as Sustainable Regional Development Opportunities The Institute of the Republic of Slovenia for Nature Conservation http://www.natreg.eu/pohorje/. Accessed 10. 2. 2012.

Nordström, E.-M., Eriksson, L.O., Öhman, K., 2010. Integrating multiple criteria decision analysis in participatory forest planning: Experience from a case study in northern Sweden. Forest Policy and Economics 12, 562-574.

Oblak, L., Glavonjić, B., 2015. A Model for the Evaluation of Radio Advertisements for the Sale of Timber Products. Drvna industrija 65, 303-308.

Pesonen, M., Ahola, J., Kurttila, M., Kajanus, M., Kangas, J., 2001. Applying A’WOT to Forest Industry Investment strategies: Case Study of a Finnish Company in North America, in: Schmoldt, D.L., Kangas, J., Mendoza, G.A., Pesonen, M. (Eds.), The analytic hierarchy process in natural resource and environmental decision making. Kluwer Academic Publisher, pp. 187198.

Punniyamoorthy, M., Mathiyalagan, P., Parthiban, P., 2011. A strategic model using structural equation modeling and fuzzy logic in supplier selection. Expert Systems with Applications 38, $458-474$.

Pur, M.M., Tabriz, A.A., 2012. SWOT Analysis using of Modified Fuzzy QFD - A Case Study for Strategy Formulation in Petrokaran Film Factory. Procedia - Social and Behavioral Sciences 41, 322-333. 
Rauch, P., 2007. SWOT analyses and SWOT strategy formulation for forest owner cooperations in Austria. Eur J Forest Res 126, 413-420.

Regan, H.M., Colyvan, M., Markovchick-Nicholls, L., 2006. A formal model for consensus and negotiation in environmental management. Journal of Environmental Management 80, 167-176.

Saarikoski, H., Mustajoki, J., Marttunen, M., 2013. Participatory multi-criteria assessment as 'opening up' vs. 'closing down' of policy discourses: A case of old-growth forest conflict in Finnish Upper Lapland. Land Use Policy 32, 329-336.

Saaty, T.L., 1980. The Analytic Hierarchy Process. McGraw-Hill, New York.

Saaty, T.L., 2005. Theory and Applications of the Analytic Network Process: Decision Making with Benefits, Opportunities, Costs, and Risks. RWS Publications, Pittsburgh.

Sevkli, M., Oztekin, A., Uysal, O., Torlak, G., Turkyilmaz, A., Delen, D., 2012. Development of a fuzzy ANP based SWOT analysis for the airline industry in Turkey. Expert Systems with Applications 39, 14-24.

Shakoor Shahabi, R., Basiri, M.H., Rashidi Kahag, M., Ahangar Zonouzi, S., 2014. An ANPSWOT approach for interdependency analysis and prioritizing the Iran's steel scrap industry strategies. Resources Policy 42, 18-26.

Shinno, H., Yoshioka, H., Marpaung, S., Hachiga, S., 2006. Quantitative SWOT analysis on global competitiveness of machine tool industry. Journal of Engineering Design 17, 251-258.

Smajić Hodžić, A., 2010. Analiza deležnikov na pilotnem območju Pohorje [Analysis of stakeholders in the pilot area Pohorje]; project: NATREG. The Institute of the Republic of Slovenia for Nature Conservation Ljubljana, p. 17. 
Srdjevic, Z., Lakicevic, M., Srdjevic, B., 2013. Approach of Decision Making Based on the Analytic Hierarchy Process for Urban Landscape Management. Environmental Management 51, 777-785.

Stam, A., Sun, M., Haines, M., 1996. Artificial neural network representations for hierarchical preference structures. Computers \& Operations Research 23, 1191-1201.

Stare, E., Gulič, J., 2011. Akcijski načrt za uresničevanje strateških ciljev na Pohorju [Action plan for the implementation strategic scenarios of Pohorje], p. 18, http://www.natreg.eu/pohorje/uploads/datoteke/Zaklju\%C4\%8Dna_Akcijski\%20nacrt\%20Po horje_Stare_Gulic.pdf, Accessed 27.3. 2015.

Stare, E., Softić, M., Lešnik Štuhec, T., Tekič, A., Pavletič, L., Bokal, S., 2011. Akcijski načrt Osnutka načrta upravljanja pilotnega območja Pohorje [Action plan of Draft management plan of pilot area Pohorje], project: NATREG. The Instititute of the Republic of Slovenia for Nature Conservation, Ljubljana, p. 43.

Sun, J., Li, H., 2009. Financial distress early warning based on group decision making. Computers \& Operations Research 36, 885-906.

UL, 2004. Uredba o posebnih varstvenih območjih - območjih Natura 2000 (Slovenian Decree of special protected areas), in: list, U. (Ed.), 49/04, 110/04, Uradni list.

Uratarič, N., Marega, M., 2010. Poročilo z zaključne delavnice za izdelavo analize SWOT in oblikovanje elementov vizije [Report of the final workshop of a SWOT analysis and design elements of the vision]; project: NATREG, p. 18, http://www.natreg.eu/pohorje/uploads/datoteke/Porocilo_SWOTinVIZIJA.pdf, Accessed 27. 3. 2015. 
Van Laarhoven, P.J.M., Pedrycz, W., 1983. A fuzzy extension of Saaty's priority theory. Fuzzy Sets and Systems 11, 199-227.

Wang, Y.-M., Elhag, T.M.S., 2006. On the normalization of interval and fuzzy weights. Fuzzy Sets and Systems 157, 2456-2471.

Wang, Y.-M., Luo, Y., Hua, Z., 2008. On the extent analysis method for fuzzy AHP and its applications. European Journal of Operational Research 186, 735-747.

Wei, W., Xin, D., Zongming, L., 2011. Analysis of the cumulative effect of pollution in the atmospheric environment management based on the method of ANP embedding into SWOT, 2011 International Conference on Remote Sensing, Environment and Transportation Engineering (RSETE), pp. 65-68.

Yüksel, İ., Dag`deviren, M., 2007. Using the analytic network process (ANP) in a SWOT analysis - A case study for a textile firm. Information Sciences 177, 3364-3382.

Zadeh, L.A., 1965. Fuzzy sets. Information and Control 8, 338-353.

Zadnik Stirn, L., 2006. Integrating the fuzzy analytic hierarchy process with dynamic programming approach for determining the optimal forest management decisions. Ecological Modelling 194, 296-305.

Zavadskas, E.K., Turskis, Z., Tamosaitiene, J., 2011. Selection of construction enterprises management strategy based on the SWOT and multi-criteria analysis. Archives of Civil and Mechanical Engineering 11, 1063-1082.

Zhu, K.-J., Jing, Y., Chang, D.-Y., 1999. A discussion on Extent Analysis Method and applications of fuzzy AHP. European Journal of Operational Research 116, 450-456. 
